\title{
Seasonal and spatial aspects of phytoplankton along the north-eastern coast of Lake Tanganyika
}

\author{
C. Cocquyt 1 \\ A. Caljont \\ W. Vyverman 2
}

Keywords : Phytoplankton, diatoms, Lake Tanganyika.

Phytoplankton was sampled over 10 months at five stations along the north-eastern coast of Lake Tanganyika. The biomass is composed chiefly of diatoms together with blue-green algae and, occasionally, green algae and Euglenophytes. Seasonal changes in phytoplankton composition and densities are discussed in relation with abiotic factors.

Quelques aspects des variations saisonnières et spatiales du phytoplancton le long de la côte nord-est du lac Tanganyika Mots clés : Phytoplancton, diatomées, Lac Tanganyika.

Des prélèvements de phytoplancton ont été effectués pendant 10 mois le long de la côte nord-est dans 5 stations du Lac Tanganyika. La majeure partie de la flore algale est constituée le plus souvent par les Bacillariophycées et les Cyanophycées et, plus rarement, par des Chlorophycées et des Euglenophycées. Les changements de la structure du peuplement phytoplanctonique et de la densité cellulaire sont analysés en rapport avec les facteurs abiotiques.

\section{Introduction}

Several studies have been published on the pelagic phytoplankton communities of Lake Tanganyika (West 1907, Van Meel 1954, Symoens 1955a, b, 1956, Hecky et al. 1978, Hecky \& Kling 1981, Gasse 1986, Caljon 1991 a). However, lit tle has been done on the phytoplankton of the numerous sheltered bays and lagoons of the lake (Mpawenayo 1985, 1986, Caljon 1987). In the present study spatiotemporal changes in littoral phytoplankton are described in relation to abiotic factors.

\section{Materials and methods}

General data on the study area can be found in different publications (e.g. Beadle 1974, Coulter 1963, 1977, Degens et al. 1971, Hecky et al. 1978; Hecky \& Kling 1981, Van Meel 1954, 1987, 1988).

1. Laboratorium voor Morfologie, Systematiek en Ecologie van de Planten, K. L. Ledeganckstraat, 35, 9000 Gent, Belgium.

2. Senior Research Assistant of the National Fund for Scientific Research (Belgium).
Five stations were selected along the north-eastern coast of Lake Tanganyika, on the territory of Burundi. They are all situated in the Bujumbura basin which is the shallowest of the four basins on Lake Tanganyika (Capart 1952). Sampling was done on a monthly base between October 1985 and July 1986. All samples were taken between 9 a.m. and 1 p.m. on the same day (18 october 1985, 22 November 1985, 17 December 1985, 17 January 1986, 14 February 1986, 14 March 1986, 11 April 1986, 9 May 1986, 6 June 1986 and 3 July 1986). In the study area, the wet season starts mid October and lasts until mid May, with a short period of little rainfall at the end of January. Northern winds prevail during the wet season. South-eastern winds blow during the dry season. Local disturbances due to geographic and microclimatological conditions of these general wind patterns are common over the entire year. The geographic position of the sampling stations is shown in figure 1.

\section{Sampling localities :}

- Station 1 : a rocky coast near Nyanza-Lac, in the southern part of Burundi, Samples ACBUA 475, $509,524,539,573,588,607,639,658,672$. 


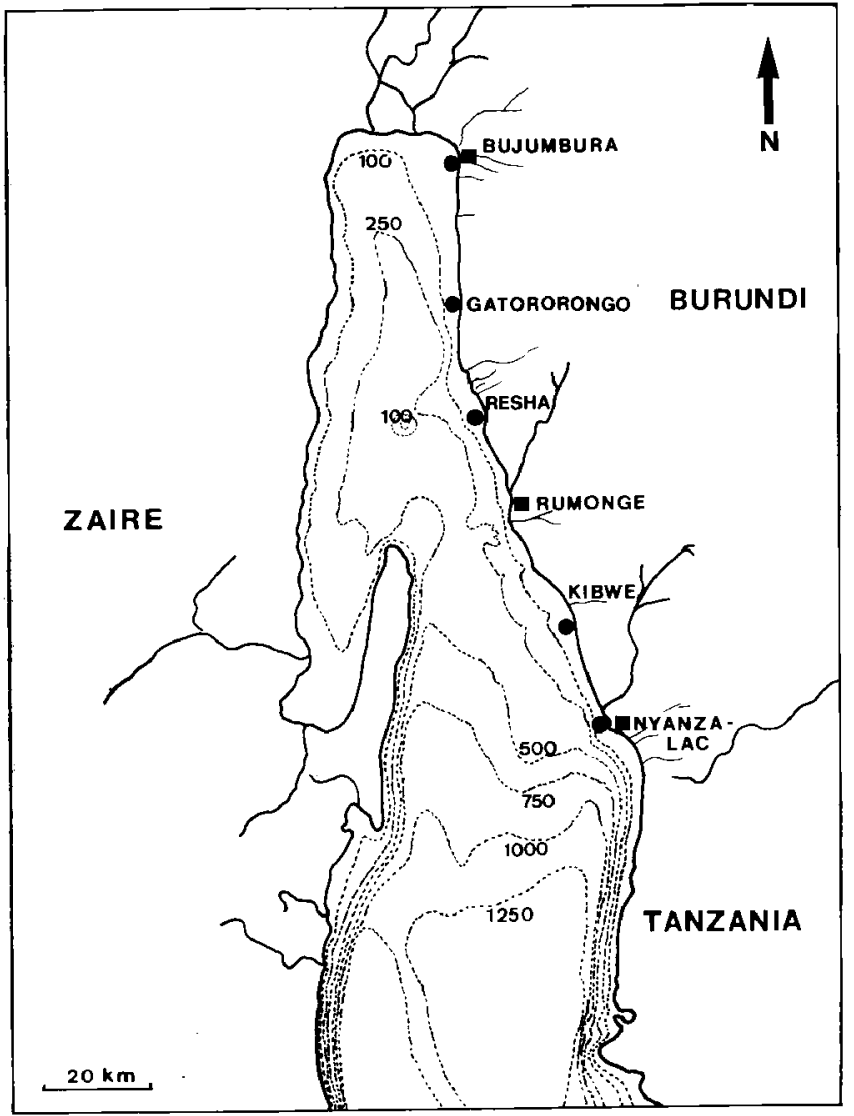

Fig. 1. Map of the northern part of Lake Tanganyika with location of the sampling stations : station 1 : Nyanza-Lac ; station 2 : Kibwe ; station 3 : Resha ; station 4 : Gatororongo; station 5 : Bujumbura. 
- Station 2 : a bay near Kibwe, $105 \mathrm{~km}$ south of Bujumbura ; the coast consists of a sandy, stony beach, tufts of Vossia cuspidata (Poaceae) are abundant. Samples ACBUA 478, 512, 527, 542, 576, 591, $609,641,660,674$.

- Station 3 : rocky coast near Resha, interspersed with a few sandy beaches, $52 \mathrm{~km}$ south of Bujumbura. Samples ACBUA 482, 516, 531, 546, $580,595,613,645,664,678$.

- Station 4 : stony beach, near Gatororongo, $28 \mathrm{~km}$ south of Bujumbura. Samples ACBUA 484, $518,533,548,582,597,615,647,666,680$.

- Station 5 : sandy beach overgrown by Phragmites mauritianus (Poaceae), situated near the " cercle nautique " at Bujumbura. Samples ACBUA 487, $521,536,551,585,600,618,650,669,683$.

Samples for quantitative investigation were taken by filling one-liter plastic pots and fixed with an acidified lugol solution. Phytoplankton samples for qualitative investigation were taken with a plankton net of $28 \mu \mathrm{m}$ mesh-size and fixed with formaldehyde. All samples are deposited in the Herbarium of gent.

Temperature, $\mathrm{pH}$ and conductivity were measured in situ with respectively a mercury thermometer, a pH meter model Schott C.G.819 and a conductivity meter model Schott C.G.857. Carbonate and bicarbonate were determined acidimetrically, chlorides titrimetrically, sulphate by nephelometry, sodium and potassium by atomic absorption spectrophotometry, calcium and magnesium by complexometry. Methodology for all abiotic factors is as described in Rodier (1978).

Phytoplankton counts were made with an inverted microscope (Reichart-Jung-Biostar) after settling of the samples in sedimentation chambers of $50 \mathrm{ml}$. Acid-cleaned subsamples for qualitative investigation of diatoms were mounted in Naphrax and studied with an Olympus BH 2 microscope equipped with phase contrast.

\section{Results}

\subsection{Abiotic factors}

Table I shows the means and standard deviations of the abiotic factors for the five sampling stations. Water temperature was at all stations between 23,5 and $30.5^{\circ} \mathrm{C}$. The $\mathrm{pH}$ is alkaline during the whole year $(8.6-9.1)$. On the whole, water temperature, $\mathrm{pH}$ and conductivity tend to be higher during the period December-March. However, between the different stations there are differences in the periods the maxima occur. No clear trend could be detected in these variations between the stations. There

Table I. Mean values and standard deviations of temperature $\left({ }^{\circ} \mathrm{C}\right.$ ), $\mathrm{pH}$, conductivity ( $\mu \mathrm{S} / \mathrm{cm}$ at $20^{\circ} \mathrm{C}$ ) and principal cations and anions (meq/1) of stations $1,2,3,4$ and 5 .

\begin{tabular}{lrrrrrrrrrrr} 
station & \multicolumn{1}{c}{1} & \multicolumn{2}{c}{2} & \multicolumn{2}{c}{3} & & 4 & \multicolumn{2}{c}{5} \\
\hline & nean & std & mean & std & mean & std & rean & std & nean & std \\
\hline teup. & 25.50 & 1.36 & 27.50 & 1.22 & 26.35 & 1.47 & 26.80 & 0.95 & 28.00 & 1.32 \\
pH & 8.87 & 0.11 & 8.89 & 0.09 & 8.93 & 0.10 & 8.91 & 0.08 & 8.85 & 0.11 \\
$\mathrm{Cond}$. & 657.00 & 18.03 & 680.80 & 20.93 & 657.60 & 21.82 & 667.20 & 17.55 & 679.80 & 11.74 \\
$\mathrm{Na}^{+}$ & 2.62 & 0.04 & 2.62 & 0.05 & 2.63 & 0.03 & 2.62 & 0.06 & 2.65 & 0.03 \\
$\mathrm{~K}^{+}$ & 0.89 & 0.07 & 0.85 & 0.06 & 0.85 & 0.04 & 0.85 & 0.02 & 0.82 & 0.04 \\
$\mathrm{Mg}^{++}$ & 3.34 & 0.10 & 3.22 & 0.14 & 3.24 & 0.12 & 3.28 & 0.14 & 3.23 & 0.07 \\
$\mathrm{Ca}^{++}$ & 0.54 & 0.01 & 0.59 & 0.03 & 0.56 & 0.10 & 0.56 & 0.07 & 0.63 & 0.12 \\
$\mathrm{CO}_{3}{ }^{--}$ & 1.22 & 0.23 & 1.32 & 0.25 & 1.35 & 0.18 & 1.35 & 0.25 & 1.30 & 0.23 \\
$\mathrm{BCO}_{3}^{-}$ & 5.10 & 0.15 & 4.97 & 0.11 & 5.01 & 0.19 & 4.95 & 0.19 & 5.02 & 0.16 \\
$\mathrm{Cl}^{-}$ & 0.95 & 0.05 & 0.93 & 0.04 & 0.93 & 0.05 & 0.93 & 0.04 & 0.93 & 0.03 \\
$\mathrm{SO}_{4}^{--}$ & 0.05 & 0.03 & 0.06 & 0.03 & 0.06 & 0.03 & 0.06 & 0.03 & 0.05 & 0.03
\end{tabular}


seems to be little spatial differences in the mean concentrations of the major ions. The cation composition is dominated by magnesium and sodium, calcium and potassium are relatively less important. The total anion concentration is dominated by bicarbonate ions. Again, there seems to be little difference between the five stations.

\subsection{Phytoplankton composition}

In the present study we will focus on the diatom part of the phytoplankton. In total, 240 different taxa belonging to 34 genera were observed. 93 taxa (distributed over 25 genera) were encountered in the quantitative countings.

The list of the observed diatom taxa is given in table II. Taxonomic remarks will be published elsewhere. Taxa marked with a "* ") were found in the countings.

In addition, 89 taxa belonging to the following taxonomic groups were observed during the quantitative investigation : 35 Cyanophyta, 11 Euglenophyta, 7 Cryptophyta, 1 Dinophyta, 3 Chrysophyta, 2 Xanthophyta, 30 Chlorophyta.

The seasonal changes in phytoplankton densities in the five stations are shown in the figures 2 to 6 . On most occasions, diatoms formed the most important part of the phytoplankton, both quantitatively and qualitatively. On average, diatoms make up for about $40-61 \%$ of the total phytoplankton density in stations 1, 3 and 4. In stations 2 and 5 they are quantitatively more important, and account for more than $88 \%$ of the total cell density. In terms of species composition, stations 1 to 4 are very similar, with Fragilaria africana, $F$. construens, Amphora pediculus, Caloneis bacillum, Cymbella minuta, Gomphonema africanum, Navicula capitata var. hungarica, N. cryptotenella, N. exigua, N. gastrum, N. pupula, N. seminuloides, Nitzschia fonticola, Rhopalodia hirundiniformis, $R$. operculata as most common taxa. Station 5 is somewhat different, Cocconeis placentula, Amphora pediculus, Capartogramma karstenii, Cymatopleura solea var. apiculara, Diploneis ovalis, Epithemia adnata, Gyrosigma wormleyi, Nitzschia lancettula, Surirella linearis were regularly found, while absent or rare in the other stations. Fragilaria construens is less important compared to the other stations.

In station 1, phytoplankton densities (Fig. 2) were low during the entire study period, with a small increase of diatoms, blue-green algae and chlorophytes at the start of the dry season.

Station 2 is characterized by much higher phytoplankton concentrations (Fig. 3) than station I. A very high maximum occurred in January, almost completely determined by diatoms, and to much lesser extent by blue-green algae. This peak is mainly accounted for by Fragilaria construens, with up to 3400 organisms/ml. Fragilaria africana, Cymbella

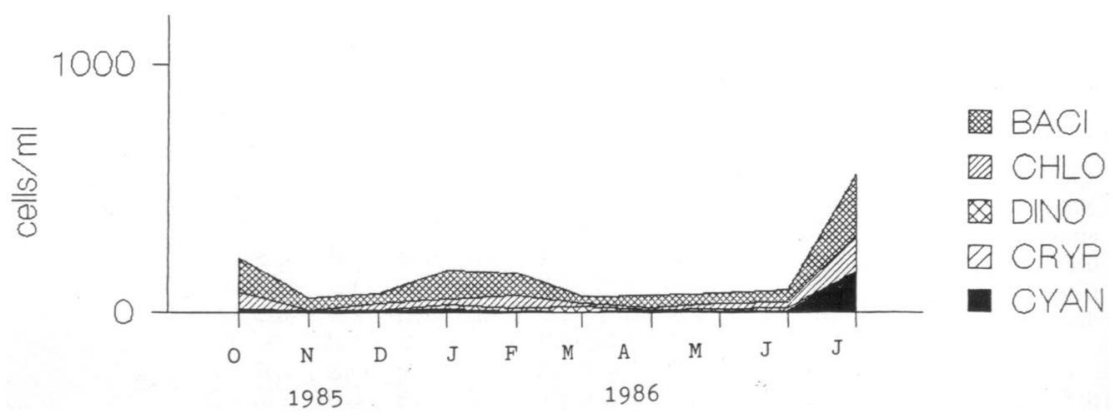

Fig. 2. Seasonal phytoplankton composition in the littoral zone of Lake Tanganyika at station 1, near Nyanza-Lac, $120 \mathrm{~km}$ south of Bujumbura. 


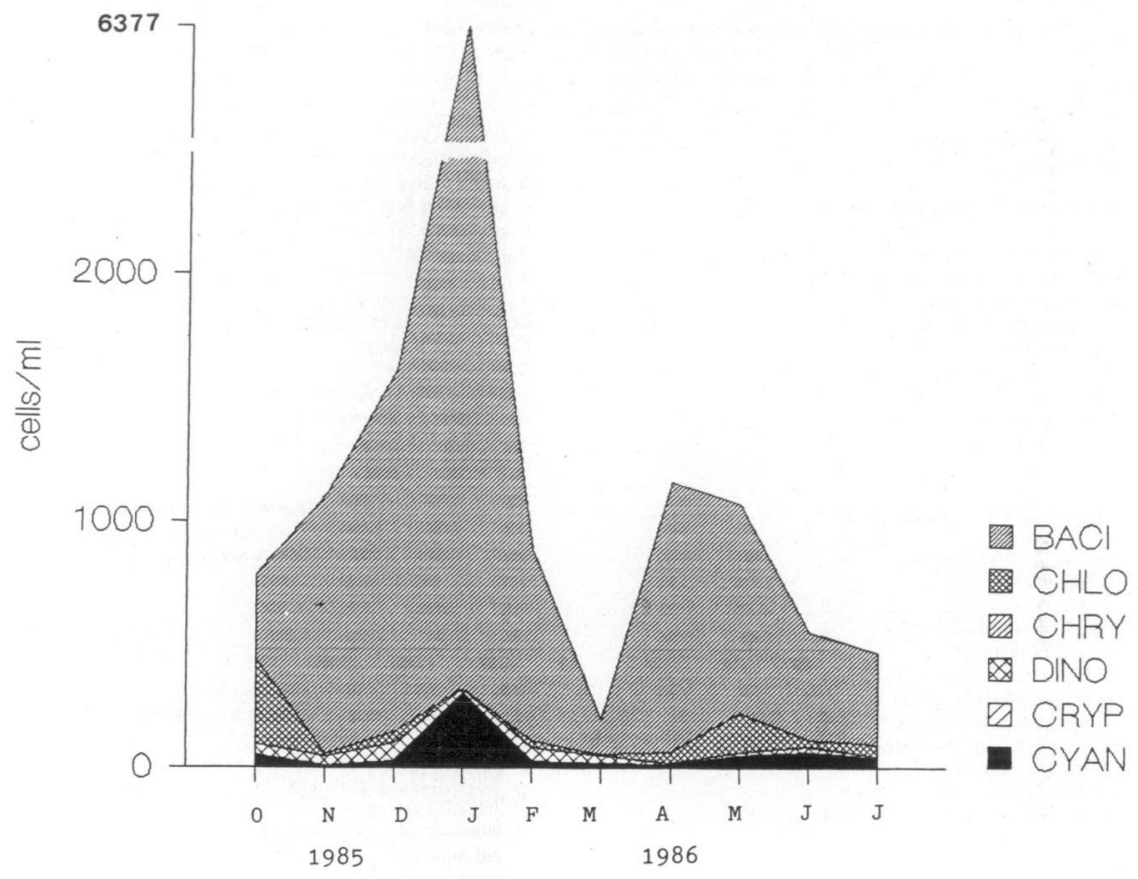

Fig. 3. Seasonal phytoplankton composition in the littoral zone of Lake Tanganyika at station 2, near Kibwe, $108 \mathrm{~km}$ south of Bujumbura.

minuta, Navicula cryptotenella, $N$. seminuloides, Nitzschia fonticola and Rhopalodia operculata attain a less important maxima. A second peak occurs in April-May, with Fragilaria construens, Gomphonema africanum and Nitzschia fonticola as dominant taxa.

Phytoplankton densities are generally low in stations 3 (Fig. 4), with a small maximum of chlorophytes at the end of the dry season, and a second smaller one in the short intermediate dry period, in January.
In station 4 phytoplankton densities (Fig. 5) are comparable to station 3 and remain fairly constant during the entire period except for a minimum in April.

In station 5 (Fig. 6) diatoms are present in great quantity during the whole study period. The most important diatoms are : Navicula exigua, Cocconeis placentula var. euglypta, Amphora pediculus, Caloneis bacillum, Cymbella minuta and Epithemia adnata, with more than 100 cells $/ \mathrm{ml}$ during one or more samplings. During the two peaks, $N$. exigua 
Table I1. Taxonomic list of the observed diatoms taxa. Taxa marked with a "* "were found in the countings.

Centrobacillariophyceae

Coscinodiscales

\author{
Aulacoseira distans (Ehr.) Simonsen \\ A. granulata (Ehr.) Simonsen \\ Orthoseira roeseana (Rabh.) OMaera \\ Cyclotella krammeri Hakansson \\ C. meneghiniana Kütz." \\ C. meduanae Germain \\ C. ocellata Pant. \\ Cyclostephanos damasii (Hust.) Stoermer \& Hakansson \\ Thalassiosira faurei (Gasse) Hasle \\ T. rudotfi (Bachmann) Hasle
}

\section{Soleniales}

Rhizosolenia eriensis H.L. Smith

Pennatibacillariophyceae

Araphidales

Fragilaria africana Hust. *

F. brevistriata Grun."

F. brevistriata var. trigibba (Pant.) Hust".

F. construens (Ehr.) Grun.*

F. construens var. subsalina Hust.

F. contruens var. venter (Ehr.) Grun.*

$F$. inflata (Heid.) Hust.

F. pinnata Ehr.

F. pinnata var. lancettula (Schumann) Hust.

Synodra acus Kütz.

S. nyansae G.S. West*

S. rumpens Kütz. var. fragilarioides Grun.

S. una (Nitzsch) Ehr."

S. uina var. aequalis (Kütz.) Hust.

S. Ulna var. danica (Kütz.) Van Heurck

S. vaucheriae Kütz.

\section{Raphidioidales}

Eunotia didyma Grun. var. tuberosa Hust.

E. monodon Ehr.

E. poctinalis (O.F. Müll.) Rabh."

E. pectinalis var. minor (Kütz) Rabh.

E. pectinalis var. ventricosa Grun."

E. polydentula Brun. var. perpusilla Grun."

\section{Monoraphidales}

Achnanthes affinis Grun.
A. buccula Chol.

A. exigua Grun.:

A. inflata (Kütz.) Grun.

A. lanceolata Bréb. ex Kütz.

A. lanceolata var. dubia Grun."

A. minutissima Kütz.

A. minutissima var. 1

A. subhudsonis Hust.

Cocconeis disculus (Schumann) $\mathrm{Cl}$.

C. hustedtii Krasske

C. placentula Ehr.:

C. placentula var. euglypta (Ehr.) $\mathrm{Cl}$.

Ahoicosphenia abbreviata (C.Ag.) Lange-Bertalot *

\section{Biraphidales}

Amphora cf calumetica (Thomas) Peragallo

A. coffeiformis (Ag.) Kütz."

A. copulata (Kütz.) Schoeman \& Archibald*

A. inariensis Krammer

A. montana Krasske

A. ovalis Kütz."

A. pediculus (Kütz.) Grun."

A. tanganyikae Caljon"

Anomoeoneis sphaerophora (Ehr.) Pfitzer

A. sphaerophora f. sculpta (Ehr.) A.M. Schmid

Caloneis aerophila Bock

C. bacillum (Grun.) Cl."

C. schumanniana (Grun.) $\mathrm{Cl}$.

c. silicula (Ehr.) $\mathrm{Cl}$.

Capartogramma amphoroides Ross*

C. crucicula (Grun. ex Cl.) Ross

C. karstenii (Zanon) Ross

Cymatopleura solea (Bréb.) W. Sm.*

C. solea var. apiculata (W. Sm.) Ralfs"

C. cakarata Hust.

Cymbella caespitosa (Kütz.) Brun.

C. cucumis A. Schmidt

C. grossestriata O. Müll.

c. minuta Hilse ex Rabh."

c. muelleri Hust.

Cymbellonitzschia minima Hust.

Diploneis finnica (Ehr.) $\mathrm{Cl}$

D. ovalis (Hilse) Cl."

Epithemia adnata (Kütz.) Bréb."

E. argus (Ehr.) Kutz.

E. sorex Kütz

Frustulia homboides (Ehr.) De Toni *

F. homboides var. crassinervia (Bréb.) Ross

F. homboidas var. saxonica (Rabh.) De Toni 
F. vulgaris (Thwaites) De Toni

Gomphocymbella boccarii (Grun.) Fort*

G. gracilis Hust.

Gomphonema aequatoriale Hust.

G. affine Kütz.

G. atricanum G.S. West"

G. augur Ehr. var. turris (Ehr.) Lange-Bertalot

G. clevei Fricke

G. gracile Enr *

G. parvulum (Kütz.) Kütz. •

Gomphonitzschia ungeri Grun."

Gyrosigma acuminatum (Kütz) Rabh.

G. attenuatum (Kütz.) Rabh."

G. nodiferum (Grun.) Reimer*

G. scalproides (Rabh.) $\mathrm{Cl}$.

G. spenceri (Quekett) Griffith \& Henfrey

G. wormleyi (Sulliv.) Boyer*

Hantzschia amphioxys (Ehr.) Grun."

$H$. amphioxys var. africana Hust.

$H$. virgata (Roper) Grun.

Navicula absoluta Hust.

$N$ amplectens Hust.

$N$ arvensis Hust.

N. bacillum Ehr.

N. barbarica Hust."

N. capitata Ehr. var. hungarica (Grun.) Ross

N. capitatoradiata Germain

N. cincta (Ehr.) Ralis*

N. confervacea (Kütz.) Grun."

N. contenta Grun.

N. costulata Grun.

N. cryptotenella Lange-Bertalot*

N. cuspidata (Kütz.) Kütz.

N. damasii Hust.

N. decussis Ostrup

N. erifuga Lange-Bertalot

N. exigua (Grég.) Grun.*

N. fossalis Krasske var. obsidialis (Hust) Lange-Bertalot

N. gallica (W.Sm.) Van Heurck

N. gallica var. perpusilla (Grun.) Lange Bertalot

N. gastrum (Ehr) Kütz.

N. gastrum var. signata Hust

N. goeppertiana (Bleisch) H.L. Smith

N. hambergii Hust

$N$. hasta Pant."

N. Lapidosa Krasske

N. modica Hust. *

$N$. monoculata Hust. var. omissa (Hust.) Lange-Bertalot
N. mutica Kütz.

N. mutica t. intermedia Hust.

N. muticoides Hust.

N. ablonga (Kütz.) Kütz.

N. paramutica Bock

N. pertatoides (O. Müll.) Hust.

N. perparva Hust

N. placentula (Ehr.) Kütz

N. platycephala O. Mül.

N. pupula Kütz."

N. pupula var. nyassensis (O. Müll.) Lange-Bertalot

N. pygmaea Kütz."

N. aff. Tynchocephala Kütz:

N. rotaeana (Rabh.) Grun.

N. rotunda Hust.

N. schroeteri Meister

N. scutelloides W. Sm, ex Greg.

N. seminuloides Hust.

N. subrhynchocephala Hust."

N. trivialis Lange-Bertalot

N. viridula (Kütz.) Ehr."

N. viridula var. rostellata (Kütz.) $\mathrm{Cl}$.

N. zanonii Hust

Noidium ampliatum (Ehr.) Krammer*

N. dubium (Ehr.) $\mathrm{Cl}$.

N. inidis (Ehr.) Cl

Nitzschia acicularis (Kütz.) W.Sm.

N. adapta Hust."

N. aequalis Hust."

$N$ amphibia Grun.

$N$ archibaldii Lange-Bertalot

N. asterionelloides O. Müll."

$N$. bacillum Hust."

N. calida Grun."

N. capitellata Hust.

N. Compressa (Bailey) Boyer var. vexans (Grun.) Lange-

Bertalot

N. constricta (Kütz) Ralfs

N. dissipata (Kütz.) Grun.

N. epiphyticoides Hust."

N. tonticola Grun."

N. Insstulum (Kütz.) Grun.

N. gracilis Hantzsch

N. inconspicua Grun.*

$\boldsymbol{N}$ intermedia Hantzsch

N. lacustris Hust.

N. lancettula $O$. Müll."

N. levidensis (W. Sm.) Grun var. victoriae (Grun.) Chot. 
N. liebetnuthii Rabh.

N. linearis W. Sm.

N. linearis var.tenuis (W.Sm.) Grun.

N. nana Grun.

N. nyassensis $O$. Müll. *

N. obtusa W. Sm. var. schweinfurthii Grun.

N. palea (Kütz.) W. Sm."

$N$. palea var. tenuirostris Lange-Bertalot*

N. paleacea (Gun.) Grun."

N. recta Hantzsch

N. rovorsa W. Sm.

N. sigma (Kütz.) W. Sm.

$N$. aff. sigmaformis Hust.

N. siliqua Archibald"

N. spiculum Hust.

N. subacicularis Hust.

N. tubicola Grun.

N. umbonata (Ehr.) Lange-Bentalot

N. vitrea Noman

Pinnularia acrosphaeria Rabh.

$P$. borealis Ehr.

$P$. borealis f. rectangularis Carlson ${ }^{*}$

P. gibba Ehr.:

P. legumen (Ehr.) Ehr.

P. microstauron (Ehr.) Cl.*

P. obscura Krasske*

$P$. scaettae Zanon

P. stomatophora (Grun.) $\mathrm{Cl}$.

$P$. subcapitata Greg.

P. tropica Hust.

$P$. viridis (Nitzsch) Ehr.

Rhopalodia gibba (Ehr.) O. Müll

A. gracilis $O$. Müll."
R. hirundiniformis $\mathrm{O}$. Müll."

R. operculata (Ag.) Hakansson*

R. mopala (Ehr.) Hust."

Stauroneis anceps Ehr.

$S$. Obtusa Lagerst.

S. phoenicenteron (Nitzsch) Ehr.

Surirella acuminata Hust.

S. angustata Kütz.

S. cf. astridae Hust.

S. biseriata Bréb.

S. brevicastata O. Mull.

S. brevicostata var, constricta Hust.

$S$. debesii Hust.

$S$. cf. elegantula Hust.

S. engleri $\mathrm{O}$. Müll.

$S$. fasciculata $O$. Mall.

S. fuellebornir $\mathrm{O}$. Müll.

S. fuellebornii var. elliptica O. Müll.

S. heidenii Hust.

S. Panceltula Hust.

S. linearis W. Sm.*

$S$. muelleri Hust (non Fort)

$S$. nyassae $O$. Müll.

S. obtusiuscula G.S. West

S. plana G.S. West

S. reichehii Hust.

S. sparsipunctata Hust."

S. sparsipunctata var. laevis Hust.

S. spiraloides Hust.

S. subcontorta Hust.

S. tenera Greg."

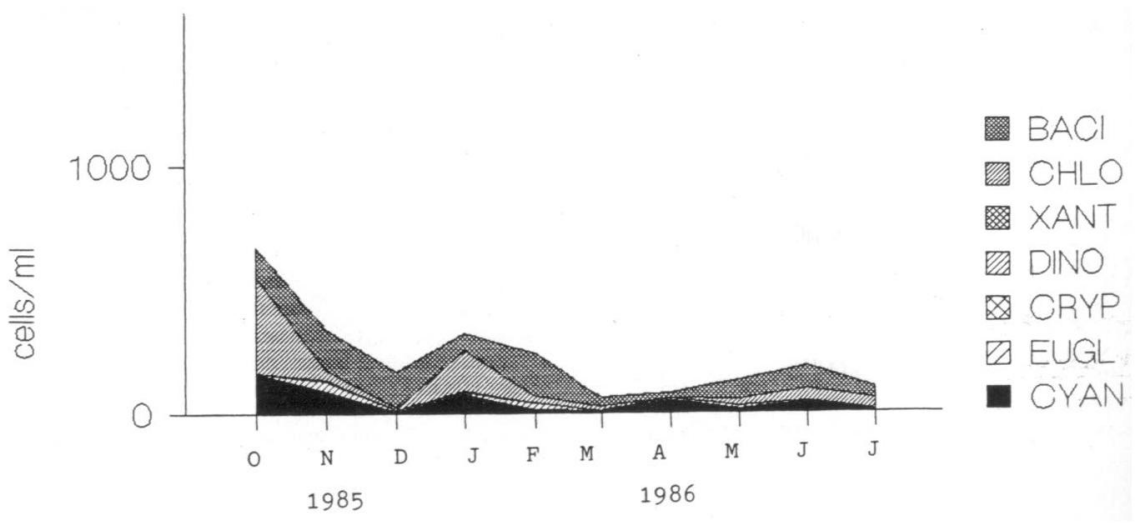

Fig. 4. Seasonal phytoplankton composition in the littoral zone of Lake Tanganyika at station 3, near Resha, $52 \mathrm{~km}$ south of Bujumbura. 


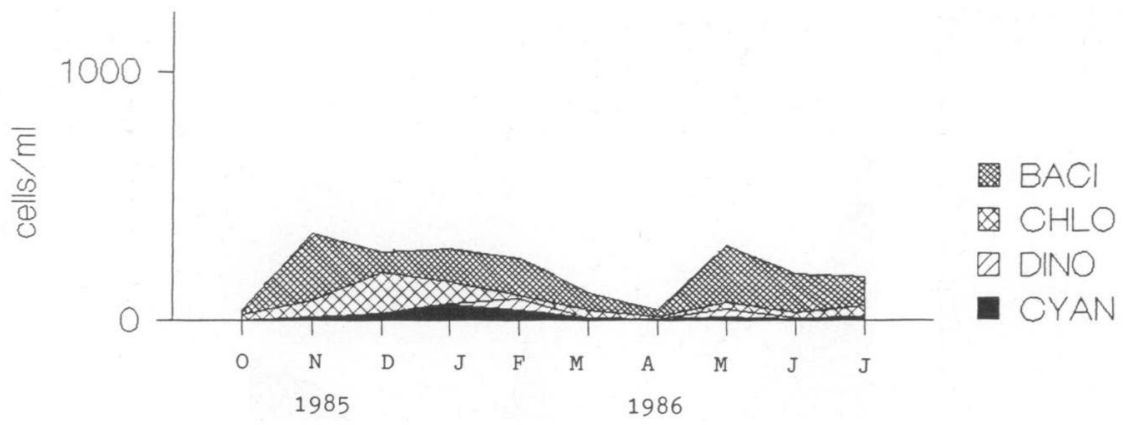

Fig. 5. Seasonal phytoplankton composition in the littoral zone of Lake Tanganyika at station 4 , near Gatororongo, $28 \mathrm{~km}$ south of Bujumbura.

is the most important taxon, with more than 1300 cells $/ \mathrm{ml}$ at the end of the dry season and 560 cells $/ \mathrm{ml}$ in March.

\section{Discussion}

On average, the water chemistry of the coastal waters seems to be similar to more pelagic stations (Hecky et al. 1978, Beauchamp 1946, Talling \& Talling 1965). However, the mean concentrations of sulphate and calcium were lower while chlorides were slightly higher than in the off-shore waters. The $\mathrm{Cl} / \mathrm{SO}_{4}$ ratio was about 14 , the $\mathrm{Mg} / \mathrm{Ca}$ ratio about 3,7 .

The seasonal variations in the concentration of the major ionic constituents seem to be quite unpredictable. No clear trends were found between the stations. Local effects of rainfall, input of water from small rivers and local mixing of the shallow water may be of more importance than general trends described from the pelagic area of the lake.

In the pelagic region of the northern lake basin, Hecky et al. (1978) found 103 algal taxa : 21 Cyanophyta, 1 Euglenophyta, 5 Cryptophyta, 9 Dinophyta, 13 Chrysophyta, 36 Chlorophyta and 18 Bacillariophyta. Phytoplankton composition in the littoral region of Lake Tanganyika mainly differs from the pelagic region in the greater diversity of diatoms. Dinophyta and Chrysophyta on the other hand, seem to be better represented in the pelagic region.

In total, we observed 240 diatom taxa, 93 of which were found in the quant itative countings. However, many diatoms also occur in surface sediments (Caljon 1991 b, Caljon \& Cocquyt 1991) and can probably be considered as tychoplanktonic. Suspension of these organisms can be induced by the often strong wind action along the coast line of the lake and by local circulation of the water column due to the input of river water. The important contribution of tychoplanktonic diatoms in the plankton communities is well illustrated by their great abundance in stations 2 and 5 . These stations are situated near sandy beaches, while in the other stations, rocky substrates prevail.

Coulter (1976) described a northward movement of enriched epilimnion by winds, from an upwelling in April-May off the coast in Zambia. This should result in a gradual increase in the plankton in Burundi, reaching a maximum in SeptemberOctober. As it is apparent from our results, this theory does not fit to the littoral plankton of the lake. Again, local conditions seem to be more important for the development and seasonal evolution of the in-shore plankton. 


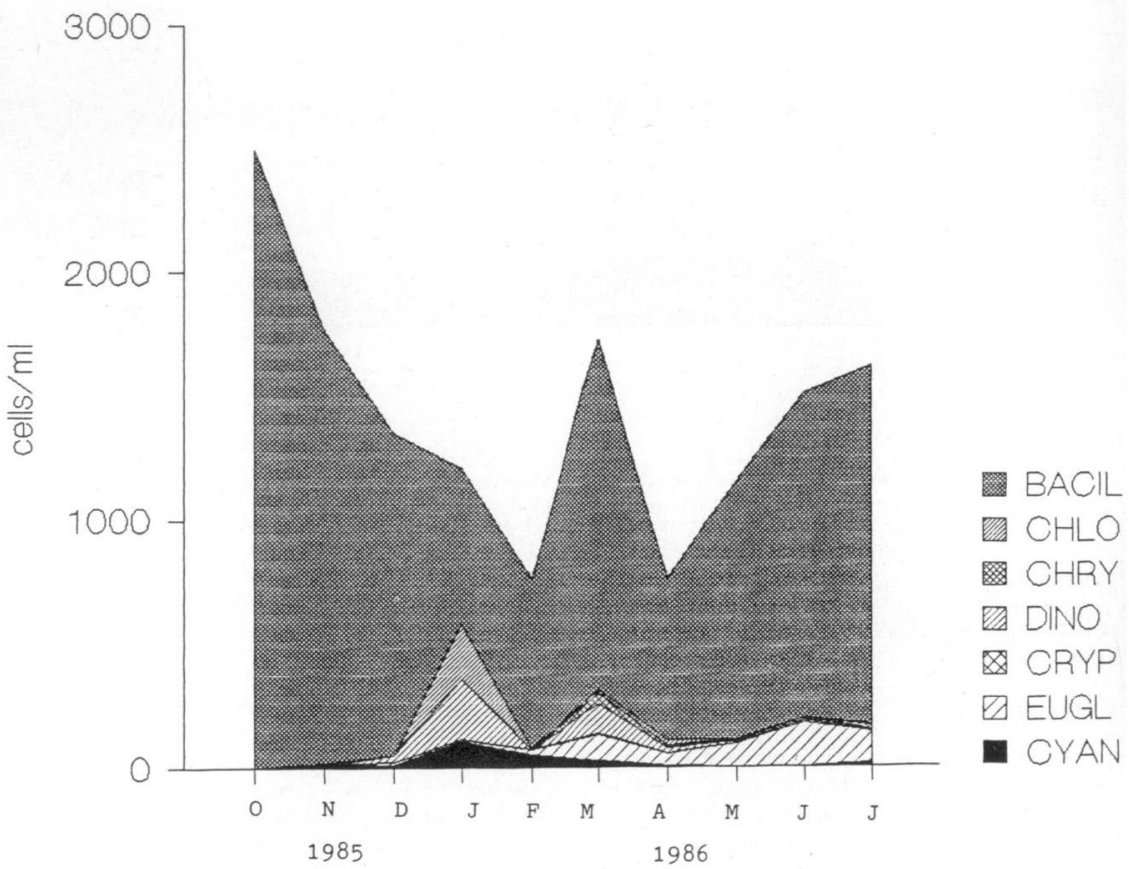

Fig. 6. Seasonal phytoplankion composition in the littoral zone of Lake Tanganyika at station 5 , near the "Cercle Nautique " at Bujumbura.

The greater number of algae in station 5 , in the city of Bujumbura, points out to a certain pollution. Caljon (1991 a) found also higher nutrient values in the Bay of Bujumbura, compared to the rest of the northern basin of Lake Tanganyika, due to pollution and mixing of surface water with bottom deposits. This is also suggested by the abundance of Euglenophytes in this station.

\section{Acknowledgements}

We are grateful to the University of Burundi for its logistic support and to $\mathrm{D} r$. P. Compere for critically reading the manuscript.

\section{References}

Beadle (L.C.). 1974. - The intand waters of tropical Africa. An introduction to tropical limnology. Longman, London $365 \mathrm{p}$.

Beauchamp (R.S.A.). 1946. - Lake Tanganyika. Narure, 157 : 183.

Caljon (A.G.). 1987. - A recently landlocked brackish-water lagoon of Lake Tanganyika : physical and chemical characteristics, and spatio-temporal distribution of phytoplankton. Hydrobiologia, 153 : 55-70.

Caljon (A.G.) 1991 a. - Water quality in the Bay of Bujumbura (Lake Tanganyika) and its influence on phytoplankton composition. SIL Mitteilungen : in press. 
Caljon (A.G.). 1991 b. - Sedimentary diatom assemblage in the northern part of Lake Tanganyika. Hydrobiologia, 226 (3) : 179-192.

Caljon (A.) \& Cocquyt (C.) 1991 , - Diatoms from surface sediments of the northern part of Lake Tanganyika. Hydrobiologia, in press.

Capart (A.). 1952. - Sondages et carte bathymétrique. Résult. Explor. Hydrol. Lac Tanganyika (1946-1947). Inst. Roy. Sci. Not. Belg., 2 (2) : 16 p.

Coulter (G.W.). 1963. - Hydrological changes in relation to biological production in southern Lake Tanganyika. Limnol. Oceanogr, $8: 463-477$.

Coulter (G.W.). 1977. - Approaches to estimating fish biomass and potential yield in Lake Tanganyika. J. Fish. Biof., 11: 393-408.

Degens (E.T.), Von Herzen (R.P.) \& Wong (H.K.). 1971. - Lake Tanganyika. Water chemistry, sediments, geological structure. Naturwissenschaften 58:229-240.

Gasse (F.). 1986. - East African diatoms. Taxonomy, ecological distribution. Bibliotheca Diatomologica 11. Cramer, Berlin-Stuttgart : $202 \mathrm{p}$. $+44 \mathrm{pl}$.

Hecky (R.E.), Fee (E.J.), Kling (H.J.) \& Rudd (J.W.). 1978. Studies on the planktonic ecology of Lake Tanganyika. Fish. Mar. Serv. Tech., Report 816: |-51.

Hecky (R.E.) \& Kling (H.J.). 1981. - The phytoplankton and protozooplankton of the euphotic zone of Lake Tanganyika : species composition, biomass, chlorophyll content and spatiotemporal distribution. Limnol, Oceanogr., $26: 548-564$.

Mpawenayo (B.). 1985. - La flore diatomique des rivières de la plaine de la Rusizi au Burundi. Bull. Soc. Roy. Bot. Belg., $118: 141-156$.

Mpawenayo (B.). 1986. - De waters van de Rusizi-vlakte (Burundi) : Milieu, algenflora en -vegetatie. V.U.B. Fac. Wet., Doktoraatsthesis, Bruxelles : $270 \mathrm{p} .+64 \mathrm{pl}$.
Rodier (J.). 1978. - L'analyse de l'eau. Dunod, Paris, 1136 p. Symoens (J.J.). 1955 a. - Observation d'une fleur d'eau à Cyanophycées au Lac Tanganyika. Folia Scient. Afr. Centr., ] (3) : 17 .

Symoens (J.J.). 1955 b. - Sur le maximum planctonique observé en fin de saison sèche dans le bassin nord du Lac Tanganyika. Folia Scient. Afr. Centr., 1 (4) : 12.

Symoens (J.J.). 1956. - Sur la formation de "fleurs d'eau " à Cyanophyceae (Anabaena flos-aquae) dans le bassin nord du lac Tanganyika, Bull. Acad. Sci. Colon. Belg., 2 : $414-419$.

Talling (J.F.) \& Talling (I.B.). 1965. - The chemical composition of African lake waters. Int. Revue ges. Mydrobiol., 50 (3) : 421-463

Van Meel (L.). 1954. - Le phytoplancton. Résult. Explor. Hydrol. Lac Tanganyika (1946-1947). Inst. roy. Sc. nat. Betg., 4: $68 ! \mathrm{p}$.

Van Meel (L.). 1987, - Contribution à la limnologie de quatre grands lacs du Zaire Oriental : Tanganyika, Kivu, Mobutu, Idi Amin. Les paramètres chimiques. Fasc. A : Le Lac Tanganyika. Inst, roy. Sc. nat. Belg. Documents et Travail. 41 : $116 \mathrm{p}$.

Van Meel (L.). 1988. - Contribution à la limnologie de quatre grands lacs du Zaire Oriental : Tanganyika, Kivu, Mobutu, Idi Amin. Les paramètres chimiques. Fase. B : Le Lac Tanganyika. Inst, roy. Sc. not. Belg. Documents et Travail. 49 : $82 \mathrm{p}$.

West (G.S.). 1907. - Report on the freshwater algae including phytoplankton of the third Tanganyika Expedition conducted by Dr W. A. Cunnington 1904-1905. J. Linn. Soc. (Bot.) $38: 8 \mathrm{l}-197$. 